\title{
Pengaruh Pembelajaran FIRE-UP Terhadap Hasil Belajar Fisika Siswa Kelas X MAN 2 Model Palu
}

\author{
Lisman, H. Fihrin dan Muh. Jarnawi \\ Bulia.lisman@yahoo.co.id \\ Program Studi Pendidikan Fisika FKIP Universitas Tadulako \\ Jl. Soekarno Hatta Km. 9 Kampus Bumi Tadulako Tondo Palu - Sulawesi Tengah
}

Penelitian ini bertujuan untuk mengetahui pengaruh pembelajaran FIRE-UP terhadap hasil belajar fisika siswa kelas X MAN 2 Model Palu. Penelitian ini merupakan penelitian eksperimen kuasi menggunakan desain The non ekuivalen Prestest-postest design. Populasi penelitian ini adalah seluruh siswa kelas X MAN 2 Model Palu. Teknik pengambilan sampel adalah purposive sampling. Kelas X MIA 3 sebagai kelas eksperimen dan kelas $X$ MIA 4 sebagai kelas kontrol. Instrumen yang digunakan berupa tes hasil belajar fisika dalam bentuk tes pilihan ganda berjumlah 20 soal telah di validasi melalui validitas tes. Berdasarkan hasil belajar siswa diperoleh rerata skor pretest hasil belajar fisika siswa kelas eksperimen adalah 6,26 dan untuk posstest adalah 13,98. Untuk kelas kontrol diperoleh rerata skor pretest 5,31 sedangkan untuk posstest adalah 6,02. Analisis data dilakukan dengan teknik statistik uji-t dua pihak untuk menguji perbedaan rerata skor hasil belajar siswa dengan signifikansi $\alpha=0,05$ dengan kriteria pengujian $H_{0}$ jika $t_{\text {hitung }}<t_{\text {tabel }}$ untuk harga $t$ lainnya $H_{0}$ ditolak.

Bedasarkan hasil analisis data diperoleh nilai $t_{\text {hitung }}=1,93>t_{\text {tabel }}=1,68$. Hal tersebut berarti bahwa nilai $t_{\text {hitung }}$ berada diluar daerah penerimaan $\mathrm{H}_{0}$. Dengan demikian disimpulkan bahwa, terdapat pengaruh pembelajaran FIRE-UP terhadap hasil belajar siswa. Berdasarkan perhitungan uji N-Gain diperoleh nilai N-Gain sebesar 22,43 yang berarti terdapat peningkatan hasil belajar siswa dalam kategori rendah.

Kata Kunci : Pembelajaran FIRE-UP, Hasil Belajar Fisika

\section{PENDAHULUAN}

Proses belajar mengajar merupakan suatu proses yang mengandung serangkaian perbuatan guru dan siswa atas dasar hubungan timbal balik yang berlangsung dalam situasi edukatif untuk mencapai tujuan tertentu, dengan kata lain proses belajar mengajar meliputi kegiatan yang dilakukan guru mulai dari perencanaan, pelaksanaan kegiatan sampai evaluasi dan program tindak lanjut yang berlangsung dalam situasi edukatif untuk mencapai tujuan tertentu dalam pengajaran. Kemampuan mengelola proses belajar mengajar adalah kesanggupan atau kecakapan para guru dalam menciptakan suasana komunikasi antara guru dan siswa sebagai upaya agar tercapai tujuan pengajaran [1].

Dalam proses belajar mengajar di sekolah pembelajaran cenderung bersifat konvensional belum memberikan banyak kesempatan bagi siswa untuk belajar dan berkembang. Akibatnya kemandirian siswa dalam belajar kurang terlatih dan proses pembelajaran akan berlangsung secara kaku sehingga kurang mendukung pengembangan pengetahuan, sikap dan keterampilan siswa. Hal ini menunjukkan bahwa penerapan suatu strategi pembelajaran yang sesuai dengan kebutuhan pembelajaran pada setiap bidang studi belum maksimal. Karena hal tersebut merupakan faktor yang dapat mempengaruhi pencapaian hasil belajar siswa, termasuk mata pelajaran fisika [2].

Pada dasarnya, pembelajaran fisika identik dengan kegiatan mencari tahu dan memahami alam serta gejalanya secara kritis dan sistematis, sehingga pembelajaran fisika bukan hanya untuk penguasaan kumpulan-kumpulan fakta dan teori saja, tetapi juga merupakan proses penemuan dan diaplikasikankan dalam kehidupan. Oleh karena itu, proses pembelajaran fisika harus dilaksanakan sesuai dengan tuntutan standar proses yang telah ditentukan, dimana proses pembelajaran harus diselenggarakan secara interaktif, inspiratif, menyenangkan, menantang, serta memotivasi siswa untuk dapat berpartisipasi aktif, kreatif, dan mandiri dalam rangka mengembangkan ide-ide dan pola pikirnya sesuai dengan bakat dan minat yang dimiliki [3].

Berkurangnya minat belajar siswa terhadap fisika berdampak jelas pada minimnya pengetahuan-pengetahuan yang mereka miliki. Jika pengetahuan masih minim, maka kemampuan untuk memecahkan permasalahan dalam fisika pun relatif rendah. 
Secara umum, rendahnya hasil belajar sains (fisika) siswa bisa disebabkan oleh beberapa faktor. Di antaranya adalah: guru, siswa, kurikulum, sarana dan prasarana. Sedangkan dari segi guru, masalah yang paling sering ditemui di lapangan di antaranya adalah strategi pembelajaran yang kurang bervariasi, cenderung menggunakan metode ceramah yang bersifat satu arah, cenderung mendominasi pembelajaran, hanya memberikan catatan setiap kali pertemuan dan terlalu mengandalkan LKS yang dijual penerbit tertentu, afeksi guru yang belum bisa diteladani dan yang paling sering ditemui adalah minimnya ketersediaan jumlah guru yang relevan dengan latar belakang fisika di sekolah tersebut, sehingga memungkinkan guru dari latar belakang pendidikan lain mengajarkan materi fisika. Sedangkan dari segi kurikulum, masalah yang paling sering ditemui di lapangan adalah ketidaksesuaian antara jumlah waktu yang disediakan dengan materi pelajaran yang harus dituntaskan [4].

Terkait dengan hasil analisis di atas, maka penulis tertarik untuk menerapkan suatu strategi pembelajaran yang penulis rasa cocok digunakan oleh guru dalam kondisi ini. Strategi ini dikenal dengan "strategi pembelajaran FIRE$U P^{\prime \prime}$. Salah satu keuntungan model pembelajaran ini adalah siswa dapat belajar dengan rileks, sehingga dengan kondisi tersebut diharapkan siswa akan lebih mudah memahami pelajaran. Terkait uraian di atas, maka peneliti tertarik untuk melakukan penelitian yang berjudul "Pengaruh pembelajaran FIRE-UP terhadap Hasil Belajar Fisika Siswa Kelas X di MAN 2 MODEL Palu"

\section{METODE PENELITIAN}

Penelitian ini menggunakan metode eksperimen kuasi dengan desain penelitian menggunakan "The non ekuivalen Prestestpostest design [5] Desain penelitian yang digunakan seperti pada Tabel 1.

Tabel 1 The Non Ekuivalen Pretest-Postest Desain
\begin{tabular}{|l|c|c|c|}
\hline Kelompok & $\begin{array}{c}\text { Tes } \\
\text { Awal }\end{array}$ & Perlakuan & $\begin{array}{c}\text { Tes } \\
\text { Akhir }\end{array}$ \\
\hline Eksperimen & $\mathrm{O}_{1}$ & $\mathrm{X}_{1}$ & $\mathrm{O}_{2}$ \\
\hline Kontrol & $\mathrm{O}_{1}$ & $\mathrm{X}_{2}$ & $\mathrm{O}_{2}$ \\
\hline
\end{tabular}

Populasi dalam penelitian ini adalah siswa kelas $X$ MIA MAN 2 MODEL Palu yang terdiri dari 6 kelas dengan kelas X MIA 3 sebagai kelas eksperimen yang siswanya mengikuti pembelajaran FIRE-UP dan kelas $X$ MIA 4 sebagai kelas kontrol yang siswanya mengikuti pembelajaran direct instruction.

Pengambilan sampel dilakukan menggunakan teknik purposive sampling yaitu teknik pengambilan sampel berdasarkan pertimbangan tertentu.

Instrumen yang digunakan dalam penelitian ini adalah tes untuk melihat hasil belajar siswa pada mata pelajaran fisika yang telah divalidasi oleh validator ahli. Analisis data dilakukan dengan menganalisis instrumen terlebih dahulu menggunakan uji validitas item dan reliabilitas tes yang kemudian dengan menganalisis data hasil penelitian menggunakan uji normalitas, uji homogenitas dan uji hipotesis.

\section{HASIL DAN PEMBAHASAN}

Tujuan penelitian ini untuk mengetahui pengaruh pembelajaran FIRE-UP terhadap hasil belajar siswa kelas X MAN 2 Model Palu. Data hasil belajar diperoleh melalui tes. Tes yang digunakan yaitu tes pilihan ganda dengan jumlah 20 soal. Pada awal penelitian kedua kelas terlebih dahulu diberikan tes awal. Data tes awal digunakan untuk mengetahui bahwa kedua data berasal dari varians yang sama (homogen) atau memiliki kemampuan yang sama. Hasil data pengujian dilakukan menggunakan bantuan Microsoft excel 2007. Skor hasil belajar siswa diperoleh dari tes awal dan tes akhir yang dilakukan pada masingmasing kelas yaitu eksperimen dan kontrol.Nilai rata-rata tes awal dan tes akhir dari kedua kelas dapat dilihat pada Tabel 2 .

Tabel 2 Deskripsi skor tes hasil belajar fisika kelas eksperimen dan kelas kontrol

\begin{tabular}{|l|c|c|c|c|}
\hline \multirow{2}{*}{ Uraian } & \multicolumn{2}{|c|}{ Tes Awal } & \multicolumn{2}{c|}{ Tes Akhir } \\
\cline { 2 - 5 } & $\begin{array}{c}\text { Eksperim } \\
\text { en }\end{array}$ & $\begin{array}{c}\text { Kontr } \\
\text { ol }\end{array}$ & $\begin{array}{c}\text { Eksperim } \\
\text { en }\end{array}$ & $\begin{array}{c}\text { Kontr } \\
\text { ol }\end{array}$ \\
\hline Sampel (n) & 21 & 21 & 21 & 21 \\
\hline $\begin{array}{l}\text { Nilai } \\
\text { maksimum }\end{array}$ & 10 & 10 & 13 & 12 \\
\hline $\begin{array}{l}\text { Nilai } \\
\text { minimum }\end{array}$ & 2 & 1 & 4 & 3 \\
\hline $\begin{array}{l}\text { Skor rata- } \\
\text { rata }\end{array}$ & 6,63 & 5,38 & 9,10 & 8,53 \\
\hline $\begin{array}{l}\text { Standar } \\
\text { deviasi }\end{array}$ & 2,06 & 2,42 & 3,32 & 2,06 \\
\hline
\end{tabular}

Berdasarkan Tabel 2 dapat dilihat bahwa secara kuantitas untuk tes awal dan tes akhir terdapat perbedaan hasil belajar siswa pada 
materi gerak lurus antara kelas eksperimen dan kelas kontrol. Analisis melalui uji normalitas, uji homogenitas dan uji hipotesis. Data yang akan diuji normalitas adalah data hasil tes akhir pada kelas eksperimen dan kelas kontrol. Hasil perhitungan analisis uji normalitas tes akhir menggunakan uji Chi-kuadrat dapat dilihat pada Tabel 3.

Tabel 3 Normalitas Distribusi Tes Akhirl pada Kelas Eksperimen dan Kelas Kontrol

\begin{tabular}{|c|c|c|}
\hline \multirow{2}{*}{ Uraian } & \multicolumn{2}{|c|}{ Tes Akhir } \\
\cline { 2 - 3 } & Eksperimen & Kontrol \\
\hline Sampel & 21 & 21 \\
\hline$x^{2}$ hitung & 1,96 & 1,52 \\
\hline$x^{2}$ tabel & 7,81 & 7,81 \\
\hline Keterangan & \multicolumn{2}{|c|}{ Normal } \\
\hline
\end{tabular}

Berdasarkan hasil uji normalitas pada Tabel 3, diketahui nilai $x^{2}{ }_{\text {hitung }}<x^{2}{ }_{\text {tabel }}$ atau $x^{2}{ }_{\text {hitung }}$ baik kelas eksperimen maupun kelas kontrol lebih kecil dibandingkan dengan nilai $x^{2}$ tabel. Dimana untuk kelas eksperimen 1,96 $<7,81$ dan untuk kelas kontrol $1,52<7,81$. Sesuai kriteria pengambilan keputusan, maka baik data dari kelas eksperimen maupun kelas kontrol keduanya berasal dari populasi yang terdistribusi normal

Tabel 4 Homogenitas Distribusi pada Kelas Eksperimen dan Kelas Kontrol

\begin{tabular}{|c|c|c|}
\hline \multirow{2}{*}{ Uraian } & \multicolumn{2}{|c|}{ Tes Akhir } \\
\cline { 2 - 3 } & Eksperimen & Kontrol \\
\hline$F_{\text {hitung }}$ & 1,73 & 1,73 \\
\hline$F_{\text {tabel }}$ & \multicolumn{2}{|c|}{1,98} \\
\hline
\end{tabular}

Pada pengujian homogenitas varians data dengan taraf signifikan 0,05 pada kelas eksperimen dan kelas kontrol, nilai $F_{\text {hitung }}$ kurang dari nilai $F_{\text {tabel }}\left(F_{\text {hitung }}=1,73<F_{\text {tabel }}=\right.$ 1,98). Dengan kriteria pengujian $\mathrm{H}_{0}$ diterima jika $F_{\text {hitung }} \leq F_{\text {tabel. }}$. Dari Tabel 4 dapat dilihat bahwa nilai $F_{\text {hitung berada pada daerah }}$ penerimaan $\mathrm{H}_{0}$ dengan demikian data tersebut menunjukkan kedua kelas yang dijadikan sampel berasal dari populasi yang homogen.

Tabel 5 Hasil uji peningkatan hasil belajar siswa pada kelas eksperimen dan kelas kontrol

\begin{tabular}{|c|c|}
\hline Uraian & Gain (\%) \\
\hline Kelas Eksperimen & 22,43 \\
\hline Kelas Kontrol & 18,29 \\
\hline
\end{tabular}

Berdasarkan hasil uji $\mathrm{N}$-Gain pada Tabel 5 diperoleh nilai $\mathrm{N}$-Gain sebesar 22,43 dengan kriteria skor N-Gain < 30. Disimpulkan bahwa peningkatan hasil belajar siswa rendah.

Setelah terpenuhinya uji normalitas dan homogenitas, maka dilakukan uji beda rata-rata (dua pihak) atau uji $\mathrm{t}$. Uji $\mathrm{t}$ tersebut diperoleh berdasarkan data tes akhir.

Berdasarkan hasil tes akhir diketahui $t_{\text {hitung }} \geq$ $t_{\text {tabel }}$ atau $0,32 \geq 1,68$. Hal tersebut berarti, nilai $t_{\text {hitung }}$ berada di luar daerah penerimaan $\mathrm{H}_{0}$. Demikian $\mathrm{H}_{0}$ ditolak dan $\mathrm{H}_{1}$ diterima, dan dapat disimpulkan bahwa terdapat perbedaan ratarata hasil belajar fisika antara kelompok siswa yang mengikuti pembelajaran FIRE-UP dengan model pembelajaran direct instruction atau pembelajaran langsung. Artinya, bahwa pembelajaran FIRE-UP mempengaruhi hasil belajar siswa

Berdasarkan hasil analisis skor rata-rata hasil belajar fisika tes awal siswa diketahui bahwa skor rata-rata hasil belajar fisika siswa pada kelas eksperimen dan kelas kontrol tidak berbeda jauh. Skor rata-rata hasil belajar fisika siswa kelas eksperimen adalah 6,63 dan kelas kontrol adalah 5,38. Sementara berdasarkan analisis uji-t diperoleh bahwa sebelum diberikan perlakuan dalam proses pembelajaran, tidak ada perbedaan hasil belajar fisika antara kedua kelas tersebut. Hal ini menunjukan bahwa kemampuan awal siswa dalam hasil belajar fisika pada kedua kelas ini tidak berbeda.

Setelah kedua kelas ini diberi perlakuan yang berbeda yakni pada kelas eksperimen dilakukan pembelajaran FIRE-UP dan untuk kelas kontrol dilakukan pembelajaran direct instruction. Pada penelitian ini kelas eksperimen menerima materi gerak lurus dengan menggunakan pembelajaran FIRE-UP sedangkan siswa pada kelas kontrol menerima materi gerak lurus dengan pembelajaran direct instruction. Di akhir pembelajaran siswa kemudian diberikan tes akhir. Analisis data tes akhir dilakukan dengan tujuan untuk mengetahui hasil belajar fisika.

Pada pelaksanaan pembelajaran FIRE-UP, tugas guru yang pertama adalah dimulai dengan guru menyampaikan tujuan pembelajaran dan motivasi siswa belajar, kemudian diikuti dengan mempelajari sendiri buku teks atau bahan pelajaran yang mereka miliki. Siswa diberikan tugas pendahuluan sebelum materi itu diajarkan oleh guru, sehingga siswa dalam mengerjakan tugas ini harus mempelajari sub pokok bahasan atau 
topik yang akan diajarkan. Selanjutnya siswa mendengarkan penjelasan singkat guru kemudian guru membagikan LKK kepada siswa suatu permasalahan untuk didiskusikan secara berkelompok, guru berkeliling mengawasi setiap kelompok. Kemudian guru memilih salah satu dari kelompok yang ada untuk mempresentasikan hasil diskusi mereka dan kelompok lain siap untuk mengomentari jawaban dari kelompok yang presentasi ketika terjadi perbedaan pendapat. Setelah itu guru akan menjelaskan konsep yang sebenarnya mengenai materi yang telah diajarkan. Selanjutnya guru memberikan soal untuk melihat kemampuan siswa mengenai materi yang telah diajarkan. Untuk pelaksanaan pada kelas kontrol yang menggunakan model pembelajaran direct instruction meningkat dari keadaan awal, namun peningkatannya lebih kecil dibandingkan kelas eksperimen yang menggunakan pembelajaran FIRE-UP. Hal ini disebabkan pada model pembelajaran direct instruction atau pembelajaran langsung hampir seluruh langkah - langkah pembelajarannya berpusat pada guru seperti orientasi, presentasi semua dilakukan oleh guru sehingga siswa cenderung pasif dalam pembelajaran serta pada model pembelajaran ini tidak ada tahap yang memungkinkan terjadinya interaksi antar siswa.

Hasil Penelitian ini sejalan dengan penelitian yang terdahulu yang berjudul Pengaruh Pengaruh pembelajaran FIRE - UP terhadap pemahaman konsep matematis berhasil menunjukkan bahwa model strategi pembelajaran FIRE-UP menggunakan eksperimen sederhana dan eksperimen terkontrol dapat mempengaruhi hasil belajar siswa [6]. Selanjutnya penelitian ini juga sejalan dengan penelitian sebelumnya yang menyatakan bahwa dengan penerapan strategi FIRE-UP pembelajaran berlangsung PAKEM dapat memperbaiki proses pembelajaran di kelas yang pada mulanya berpusat pada guru, akan beralih berpusat kepada siswa [7].

Berdasarkan semua data yang telah dijabarkan dapat disimpulkan bahwa, terdapat pengaruh pembelajaran FIRE-UP terhadap hasil belajar siswa MAN 2 Model Palu. Peningkatan hasil belajar tersebut terjadi karena selama proses pembelajaran siswa di tuntut untuk memecahkan masalah yang diberikan dan kemudian menjelaskannya sesuai dengan konsepnya.

Kelebihan dari pembelajaran FIRE-UP dibandingkan dengan pembelajaran langsung adalah pada sisi keaktifan siswa pemerataan pengetahuan kepada seluruh siswa saat materi ajar diberikan. Melalui pembelajaran FIRE-UP siswa dilibatkan untuk aktif berfikir dan menemukan secara langsung pengertian atau konsep yang ingin diketahuinya. Selain dari kelebihan tersebut, ada pula kekurangan dari pembelajaran FIRE-UP ini yaitu membutuhkan waktu yang cukup lama dalam untuk memperoleh kesimpulan. Kita sebagai guru (fasilitator) juga butuh kesabaran yang lebih dalam membimbing siswa agar dapat fokus dalam melakukan kegiatan pembelajaran.

\section{KESIMPULAN DAN SARAN}

Berdasarkan hasil analisis uji hipotesis diperoleh bahwa terdapat pengaruh pembelajaran FIRE-UP terhadap hasil belajar fisika siswa kelas $X$ MAN 2 Model Palu. Berdasarkan hasil uji N-Gain kelas eksperimen dan kelas kontrol diperoleh bahwa pada kedua kelas terebut terdapat peningkatan hasil beajar siswa. Namun peningkatan hasil belajar siswa dalam kategori rendah.

Berdasarkan kesimpulan ada beberapa saran yang dapat dikemukakan: (1) Pembelajaran FIRE-UP membutuhkan waktu proses yang cukup lama, sebaiknya peneliti selanjutnya dapat memperhitungkan waktu di setiap fase pembelajaran agar lebih efisien, karena waktu menjadi salah satu kendala dalam proses pembelajaran. (2) Untuk peneliti selanjutnya dapat menerapkan pembelajaran FIRE-UP dengan materi yang berbeda dan karakteristik yang berbeda sehingga dapat digunakan sebagai bahan pertimbangan dalam penerapannya di sekolah.

\section{DAFTAR PUSTAKA}

[1] Suryosubroto. (1997). Prinsip Memilih

Media Pembelajaran, Jakarta: Rineka Cipta.

[2] Oemar, H. (2007). Proses Belajar Mengajar. Jakarta: Bumi Aksara

[3] Mulyasa, E. (2008). Kurikulum Tingkat Satuan Pendidikan. Jakarta: Bumi Aksara.

[4] Sari, M. (2011) Problematika Pendidikan Dan Pembelajaran Sains Di Indonesia

[5] Sugiyono. (2010). Metode penelitian pendidikan (pendekatan kuantitatif, kualitatif dan $R \& D$. Bandung: Alfabeta

[6] Ovtaleny, M. (2012). "Pengaruh pembelajaran FIRE UP terhadap pemahaman konsep matematis".

[7] Sumargono (2012). Penerapan Strategi FIRE UP Untuk Meningkatkan Aktivitas Siswa Dalam Pembelajaran Matematika Yang Aktif, Kreatif, Efektif, dan Menyenangkan. 